\title{
Granulocyte Colony-Stimulating Factor-Primed Unmanipulated Haploidentical Blood and Marrow Transplantation
}

\section{OPEN ACCESS}

Edited by:

Antonella Mancusi,

University of Perugia, Italy

Reviewed by:

Leo Luznik,

Johns Hopkins University,

United States

Takaaki Konuma,

Institute of Medical Science, University

of Tokyo, Japan

Biju George,

Christian Medical College \&

Hospital, India

*Correspondence:

Xiao-Jun Huang

huangxiaojun@bjmu.edu.cn

Specialty section:

This article was submitted to Alloimmunity and Transplantation,

a section of the journal

Frontiers in Immunology

Received: 31 May 2019

Accepted: 09 October 2019

Published: 01 November 2019

Citation:

Chang $Y-J$, Zhao $X-Y$ and Huang $X-J$ (2019) Granulocyte

Colony-Stimulating Factor-Primed Unmanipulated Haploidentical Blood and Marrow Transplantation.

Front. Immunol. 10:2516. doi: 10.3389/fimmu.2019.02516

\author{
Ying-Jun Chang ${ }^{1}$, Xiang-Yu Zhao ${ }^{1}$ and Xiao-Jun Huang ${ }^{1,2 *}$ \\ ${ }^{1}$ Beijing Key Laboratory of Hematopoietic Stem Cell Transplantation, National Clinical Research Center for Hematologic \\ Disease, Peking University Institute of Hematology, Peking University People's Hospital, Beijing, China, ${ }^{2}$ Peking-Tsinghua \\ Center for Life Sciences, Beijing, China
}

Granulocyte colony-stimulating factor (G-CSF), a growth factor for neutrophils, has been successfully used for stem cell mobilization and T cell immune tolerance induction. The establishment of G-CSF-primed unmanipulated haploidentical blood and marrow transplantation (The Beijing Protocol) has achieved outcomes for the treatment of acute leukemia, myelodysplastic syndrome, and severe aplastic anemia with haploidentical allografts comparable to those of human leukocyte antigen (HLA)-matched sibling donor transplantation. Currently, G-CSF-mobilized bone marrow and/or peripheral blood stem cell sources have been widely used in unmanipulated haploidentical transplant settings. In this review, we summarize the roles of G-CSF in inducing T cell immune tolerance. We discuss the recent advances in the Beijing Protocol, mainly focusing on strategies that have been used to improve transplant outcomes in cases of poor graft function, virus infections, and relapse. The application of G-CSF-primed allografts in other haploidentical modalities is also discussed.

Keywords: haploidentical stem cell transplantation, granulocyte colony-stimulating factor, poor graft function, relapse, virus infections

\section{INTRODUCTION}

Allogeneic stem cell transplantation (allo-SCT) is a method for the therapeutic cure of hematological malignancies (1-3). However, donor limitations restrict the wide use of allo-SCT. In the past two decades, researchers have established several haploidentical SCT (haplo-SCT) protocols based on different approaches to induce immune tolerance (4-6). Those approaches include ex vivo graft $\mathrm{T}$ cell depletion (TCD) in combination with megadoses of $\mathrm{CD} 34^{+}$cells and/or anti-third-party $\mathrm{CD} 8 \mathrm{~T}$ cells, in vitro $\mathrm{CD} 3 \alpha \beta / \mathrm{CD} 19$ depletion, immune tolerance induced by granulocyte colony-stimulating factor (G-CSF) (7), and post-transplantation cyclophosphamide (PT/CY) for tolerance induction (8-18). Based on T cell tolerance induced by G-CSF, the Peking University group established a novel G-CSF-primed haploidentical blood and marrow transplantation system (The Beijing Protocol, Figures 1, 2) (4, 5), including individualized conditioning regimens, the combination of unmanipulated G-CSF primed blood and marrow as allografts, donor selection based on non-human leukocyte antigen (HLA) systems, risk-directed strategies for graft-vs.-host disease (GVHD) (19), and relapse. Currently, because of the shift from TCD grafts to unmanipulated marrow and/or peripheral blood harvests, haplo-SCT is easier to 


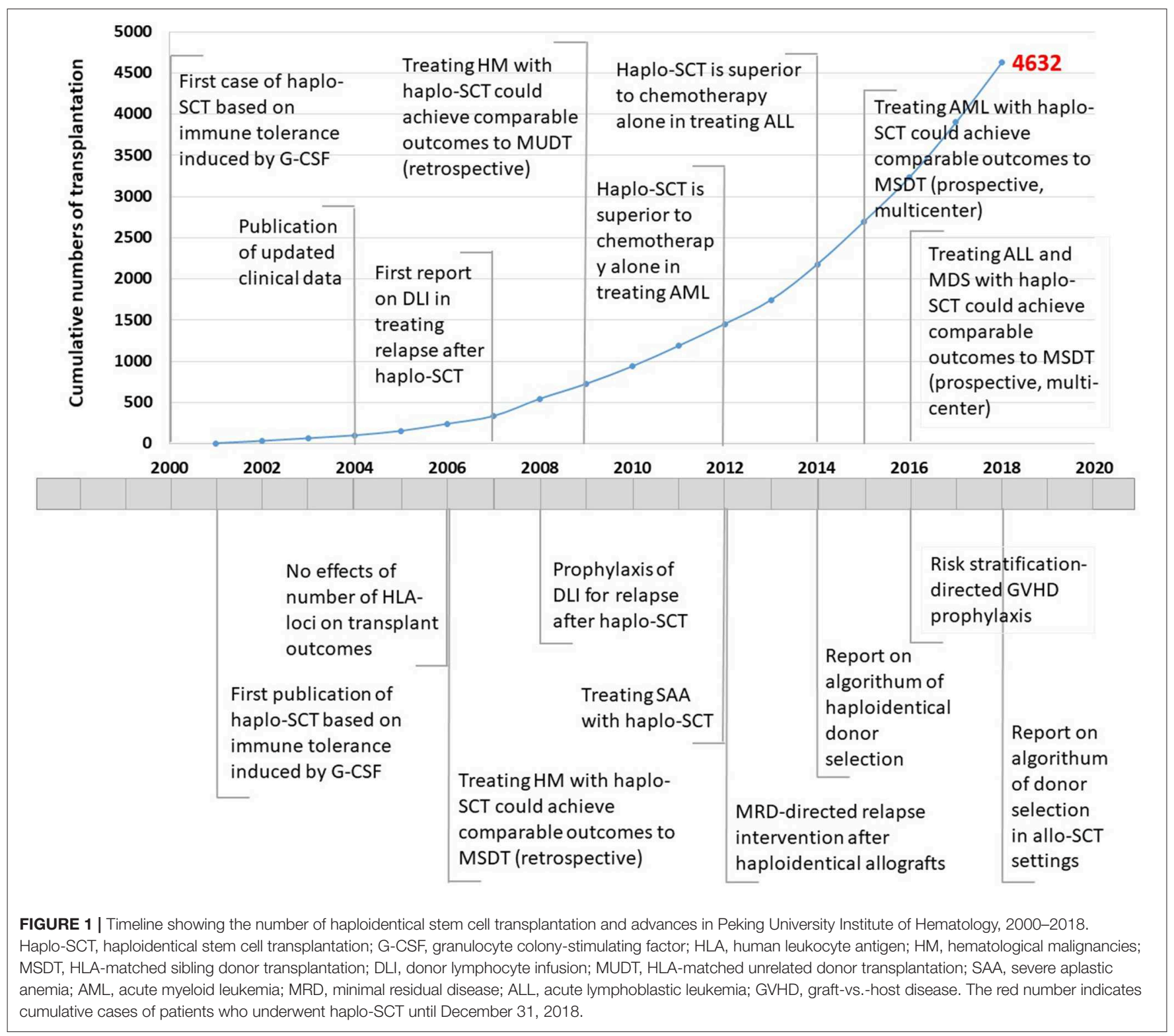

perform than before. The development and success of haploidentical allografts worldwide makes "everyone has a donor" a reality (20). Several reviews have already been published on this topic (21-25). Here, we summarize the advances in inducing $\mathrm{T}$ cell tolerance by treating healthy donors with G-CSF. We discuss the recent advances in the Beijing Protocol mainly focusing on strategies that have been used for poor graft function (PGF) (26-30), virus infections (31-33), and relapse (34-36). We also indicate the application of G-CSF-primed allografts for other haploidentical allograft modalities.

\section{T CELL TOLERANCE INDUCED BY G-CSF}

G-CSF has been widely applied to mobilize hematopoietic stem/progenitor cells in allo-HSCT settings. In the past 20 years, a number of studies support the notion that G-CSF plays an important role in regulating immune cell number and function in allografts, especially in inducing T cell tolerance (3746) Previously, researchers mainly focused on the regulatory effects of G-CSF on T cells through indirect effects, such as expanding regulatory $\mathrm{T}$ cells, $\mathrm{CD} 34^{+}$regulatory monocytes, tolerogeneic antigen presentation cells, regulatory B cells (47), $\mathrm{CD}^{+}{ }^{+} \mathrm{CD} 4{ }^{-} \mathrm{CD} 8{ }^{-} \mathrm{T}$ cells, regulatory $\gamma \delta \mathrm{T}$ cells (48), suppressor interleukin-10 (IL-10) ${ }^{+}$neutrophils, myeloid-derived suppressor cells (MDSCs) (37), and granulocytic MDSCs (also known as low-density neutrophils) (49). All of these cells could suppress T cell proliferation through IL-10, transforming growth factor- $\beta$ (TGF- $\beta$ ), nitric oxide (NO), indoleamine 2,3-dioxygenase (IDO), and/or cell contact (Figure 3).

In 2003, Franzke et al. (45) suggested that G-CSF acts as a strong immune regulator in T cells and directly modulates T-cell immune responses via its receptor on T cells. They demonstrated 


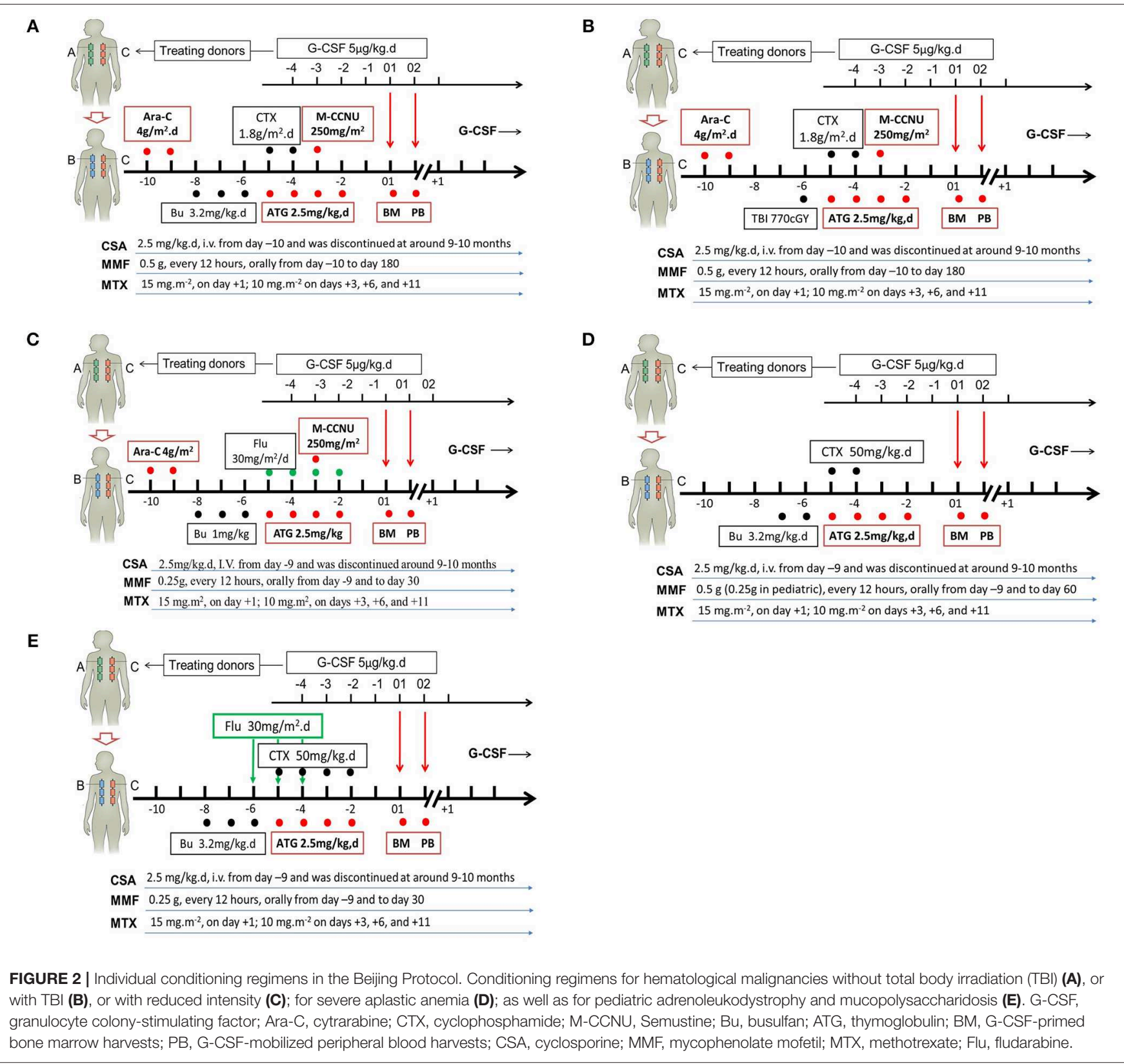

that G-CSF could limit the interferon- $\gamma$ signaling in $\mathrm{T}$ cells by suppressing the gene expression of ISGF3- $\gamma$ subunit/p48 in $\mathrm{CD}^{+}{ }^{+}$donor $\mathrm{T}$ cells. In vitro experiments also showed that the Th2 type could be induced by G-CSF through direct induction of GATA-3. In 2014, in vivo experiments also demonstrated that donor $\mathrm{T}$ cell alloreactivity could be modulated directly via binding to G-CSF receptor expressed on T cells (43). The authors reported that the protective effects of G-CSF on GVHD imparted during stem cell mobilization were totally dependent on direct signaling through the $\mathrm{T}$ cell, because WT but not G$\mathrm{CSFR}^{-/-}$donor T cells were modulated by G-CSF (43). Overall, mounting evidence indicates that G-CSF can induce $\mathrm{T}$ cell tolerance through both indirect and direct pathways (Figure 3)
(43, 45, 46), although the detailed molecular mechanisms of which remain unclear.

Clinically, Ringdén et al. (50) reported that application GCSF after bone marrow transplantation increased the cumulative incidence of grades II to IV acute GVHD, which is not consistent with above-mentioned concept. The following reasons may account for this inconsistence: First, use of G-CSF after transplantation increases the levels of soluble interleukin-2 (IL-2)-receptor-alpha that may aggravate acute GVHD (51). Second, treating healthy donors with G-CSF decreases the production of tumor necrosis factor alpha, IL-2, and interferon$\gamma$; the immunoregulatory effects of G-CSF on cytokines, T cells, and regulatory cells of donors might contribute to the lower 


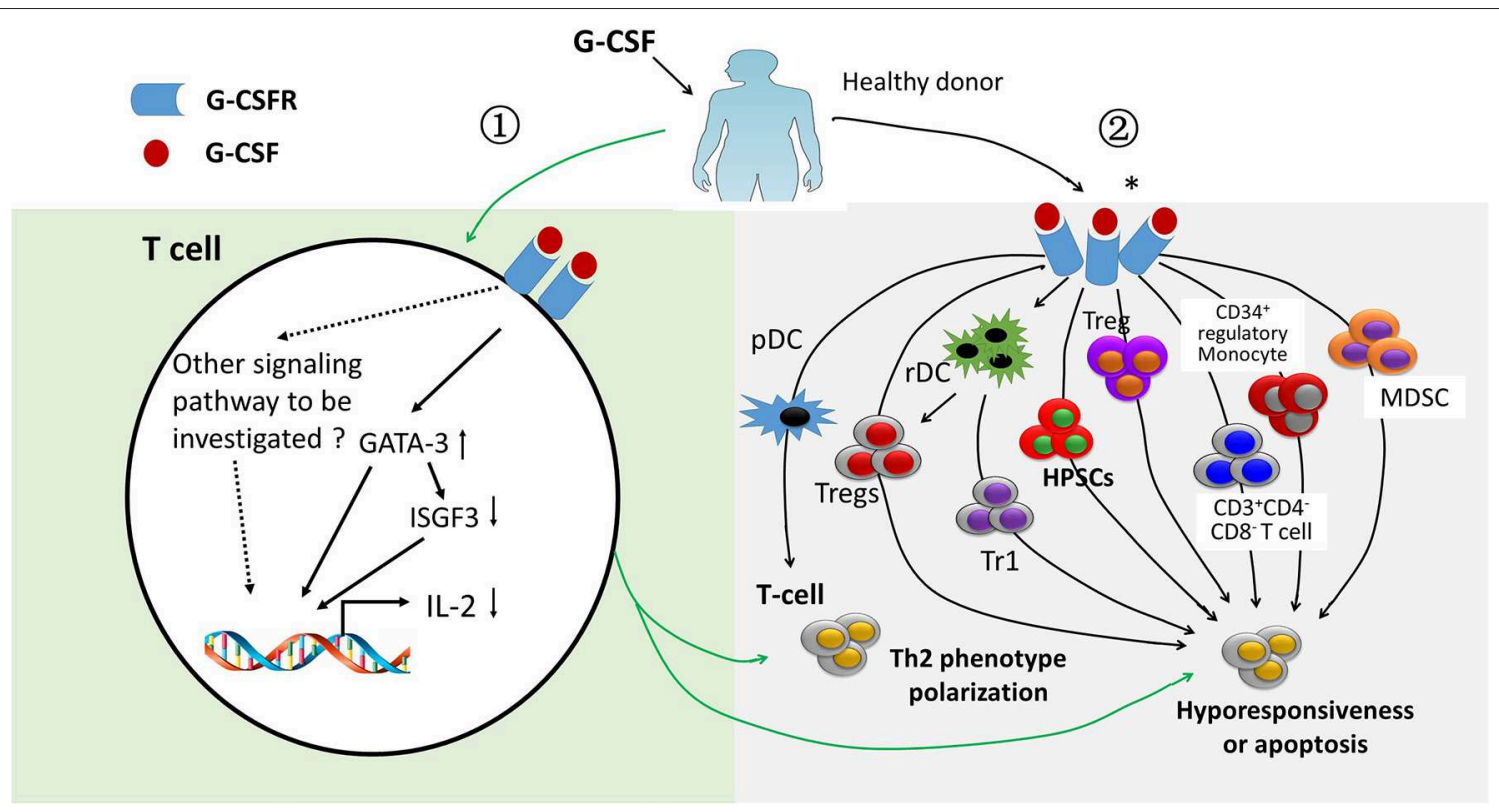

FIGURE 3 | Immune regulatory effects of treating healthy donors with granulocyte colony-stimulating factor. Granulocyte colony-stimulating factor (G-CSF) has immune regulatory effects on T cells via direct (light green area) and indirect mechanisms (light gray area). (1) ISGF-3 was down-regulated and GATA3 was up-regulated by G-CSF through binding G-CSF receptor, leading to a polarization of T cells from Th1 to Th2 phenotype as well as hyporesponsiveness of T cells (light green area). (2) Effects of G-CSF obtained from G-CSF-primed allografts on polarizing T cell from Th1 to Th2. Suppressing T cell proliferation ability by regulatory $T$ cells (Treg), type 1 Treg, CD34 ${ }^{+}$monocyte, myeloid derived suppressor cells, and $\mathrm{CD}^{+} \mathrm{CD}^{-} \mathrm{CD} 8^{-} \mathrm{T}$ cells obtained from G-CSF-primed allografts either via direct contact, cytokines, such as interleukin-10 and transform growth factor- $\beta$, or via other molecules, such as arginase-1 and reactive oxygen species (light gray area). *indicates G-CSF receptor expressed on immune cells, such as myeloid-derived suppressor cells.

incidence of GVHD after using G-CSF-primed bone marrow harvests and/or G-CSF-mobilized peripheral blood harvests as allografts $(39,46)$.

\section{RECENT ADVANCES IN THE BEIJING PROTOCOL}

The Beijing Protocol, one of the main haplo-SCT modalities, has been performed in nearly $98 \%$ of transplant centers in China (52). In the first half of 2016, the proportion of haploSCT out of the allo-HSCT had increased to $51.7 \%$ according to data reported by Xu et al. (52) on behalf of the Chinese Blood and Marrow Transplantation Register Group. Based on the Beijing experience, Di Bartolomeo et al. (53) treated 80 patient hematological malignancies by applying a modified protocol. The key characteristics of their protocol were (i) a chemotherapy-based conditioning regimen, (ii) infusion of only G-CSF-stimulated bone marrow harvests, (iii) intensified GVHD prophylaxis with anti-thymocyte globulin (ATG), cyclosporine (CSA), methotrexate (MTX), mycophenolate mofetil (MMF), and anti-CD25 antibody. Di Bartolomeo et al. (53) found that the cumulative incidence (CI) of neutrophil engraftment was $93 \%$. The 100 -day CI for II-IV grade of acute GVHD was $24 \%$. The 2-year CI of extensive chronic GVHD was 6\%. The 3year probability of overall survival (OS) and disease-free survival (DFS) for standard-risk and high-risk patients was 54 and 33\% and 44 and $30 \%$, respectively.
In a multicenter, prospective study, Wang et al. (54) showed that unmanipulated haplo-SCT achieved outcomes, including 3 -year DFS (74 vs. $78 \%, P=0.34$ ) and OS (79 vs. $82 \%$, $P=0.36$ ), similar to those of HLA-matched sibling donor transplantation (MSDT) for acute myeloid leukemia patients in complete remission 1 (CR1). In another biologically phase III randomized study, Wang et al. (55) demonstrated that the 3 -year DFS (61 vs. $60 \%, P=0.91$ ) and OS (68\% vs. $66 \%$, $P=0.81$ ) were comparable between adults with Philadelphianegative high-risk acute lymphoblastic leukemia (ALL) who underwent haplo-SCT and those who received MSDT. Similar to the report by Wang et al. (55), adults with standard-risk ALL in CR1 who underwent haplo-SCT could also achieve comparable survival to those of MSDT (56). In a registry-based study, Wang et al. (57) reported that the 4-year adjusted probabilities of OS (63 vs. $73 \%)$ and relapse-free-survival ( $63 \%$ vs. $71 \%)$ between patients who received haplo-SCT with 4-5/6 matched donors and those who received MSDT were comparable. These results were also confirmed by researchers from other centers in China (58). In Europe and the United States of America, a number of studies obtained similar results as reported by us $(54,55,57)$, that patients with hematological malignancies who underwent haplo-SCT with PT/CY could achieve comparable outcomes to those with MSDT or HLA-matched unrelated donor transplantation (59-65).

In the past 3 years, a series of studies from different transplant centers in China confirmed the efficacy, safety, and feasibility of treating adult and pediatric severe aplastic anemia (SAA) patients 
with haploidentical allografts based on G-CSF-induced immune tolerance (Table 1) (66-75). In a multicenter prospective study, $\mathrm{Xu}$ et al. (76) showed that treating SAA patients $(n=101)$ with haplo-SCT could achieve a 3 -year estimated OS (89.0 vs. $91.0 \%$, $P=0.555$ ) and failure-free survival (FFS, 86.8 vs. $80.3 \%, P=$ $0.659)$ when compared with patients $(n=48)$ who received contemporaneous transplantation from matched related donors. In another registry-based study, Xu et al. (67) further observed similar 3-year estimated OS ( 86.1 vs. $91.3 \%, P=0.358)$ and FFS ( 85.0 vs. $89.8 \%, P=0.413$ ) between the haplo-SCT and MUDT cohorts for the treatment of SAA. In this regard, Professor Neal S. Young commented that "Haploidentical transplantation has been advocated in China as first-line treatment for children" (77).

More recently, the G-CSF-based haplo-SCT protocol has been successfully used for the treatment of inherited metabolic storage diseases (IMD) and genetic diseases, such as adrenoleukodystrophy (ALD), mucopolysaccharidosis (MPS), and thalassaemia major $(78,79)$. In China, six IMD cases, including $\operatorname{ALD}(n=4)$ and MPS $(n=2)$, were treated by Chen et al. (79) with busulfan (Bu), fludarabine (Flu), and cyclophosphamide (Cy) conditioning regimen. Hematopoietic reconstitution was achieved in all cases. Four patients developed grade I-II acute GVHD, and one patient had limited chronic GVHD. After a median follow-up of 292 days, the cumulative incidence of 1-year transplant-related mortality (TRM) was $0 \%$. The 1 -year probability of OS was $100 \%$. In another study, Sun et al. (78) reported the results of eight thalassaemia major children who underwent haplo-SCT using the FBCA conditioning regimen [Flu, Bu, $\mathrm{Cy}$, and antithymocyte globulin (ATG)]. All cases achieved hematopoietic recovery after transplantation. Four (50\%) and two (25\%) cases experienced grade I-II and grade III-IV acute GVHD, respectively. One patient suffered from localized chronic GVHD of the skin. All cases survived and achieved independence from blood transfusion. The OS and transfusion-free survival rates were both $100 \%$ after a median follow-up of 36 months. These studies suggest that haplo-SCT based on G-CSF could be a feasible, safe, and efficient approach for the treatment of IMD and genetic disease.

Although the indications for haplo-SCT have been extended, and no differences in the outcomes between haploidentical allografts, that is, MSDT and MUDT, were achieved, transplant complications, such as PGF (4, 26-30, 80-83) virus infection $(31,32,84)$, and relapse (85-94), remain the major causes of morbidity and mortality. Fortunately, in recent years, some advances in the treatment of PGF, virus infections, and leukemia relapse after haplo-SCT have been made by scholars worldwide. We discuss these advances here.

\section{Mechanisms and Therapies for PGF}

PGF, which occurs in 5-26\% of cases after allo-HSCT $(26,28-30)$ has become a growing obstacle that contributes to high morbidity and mortality. PGF is defined as follows: absolute neutrophil count $\leq 0.5 \times 10^{9} / \mathrm{L}$, platelets $\leq 20 \times 10^{9} / \mathrm{L}$, or hemoglobin $\leq 70 \mathrm{~g} / \mathrm{L}$ for at least three consecutive days beyond day 28 post-transplantation with a transfusion requirement associated with hypoplastic-aplastic BM in the presence of complete donor

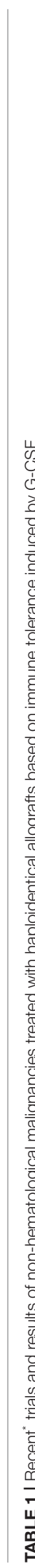

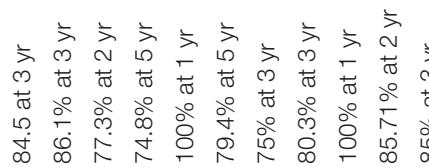

$\sum \stackrel{i}{i}$

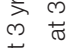

त

i

$\stackrel{1}{\Sigma}$

$\frac{\pi}{\pi}$

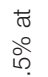

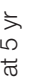
क लं 
chimerism. Previous studies by Ciurea et al. (85) showed that patients with high donor-specific anti-HLA antibody (DSA) levels (>5,000 MFI) and complement-binding DSA antibodies (C1q positive) experienced higher risk of primary graft failure. Our data demonstrated that a number of risk factors, such as infused $\mathrm{CD}_{3}{ }^{+}$cells, DSA, GVHD, and CMV infection, were associated with PGF $(86,87)$. The available therapeutic strategies for PGF patients include the administration of hematopoietic growth factors, donor lymphocyte infusion (30), a second alloHSCT, a CD34 ${ }^{+}$cell boost $(29,30)$, or mesenchymal stem cell (MSC) infusion (80, 88). Additionally, eltrombopag, an oral thrombopoietin receptor agonist, has shown promising results in severe aplasia anemia. In a recent study, 12 patients who responded poorly to standard treatments for secondary PGF after allo-SHCT were treated with eltrombopag (89). The median duration from PGF diagnosis to eltrombopag treatment was 59 (range, 30-180) days. The dose of eltrombopag was $25 \mathrm{mg} /$ day for 3 days and subsequently increased to 50 or $75 \mathrm{mg} /$ day. After treatment for 8 (range, 2-23) weeks, 10 cases responded to eltrombopag: eight cases achieved complete response (CR) and two cases achieved partial response. The median time from treatment to achieving CR was 29 (10-49) days. The 1-year probability of OS was $83.3 \%$. No TRM and no evidence of cataract, thrombosis, or any other grade 3/4 toxicities were observed (89). This result was also confirmed by Fu et al. (90) and Marotta et al. (91), suggesting that eltrombopag could be an alternative treatment for PGF.

Several studies have been reported seeking to elucidate the pathophysiology of PGF (4, 26, 27, 81-83). First, patients with PGF after allo-SCT had reduced and dysfunctional endothelial progenitor cells (EPCs) in the bone marrow microenvironment: these EPCs are characterized by impaired proliferation, migration, angiogenesis, and increased levels of ROS and apoptosis. In addition, the increased reactive oxygen species (ROS) could activate p38 and its downstream transcription factor in BM EPCs, both of which might contribute to the occurrence of PGF. Second, BM CD34 ${ }^{+}$cells are functionally normal in PGF; however, elevated ROS in CD $34^{+}$ cells might lead to exhaustion of quiescent $\mathrm{BM} \mathrm{CD} 34^{+}$cells. Third, dysregulated $\mathrm{T}$ cell responses, including a shift in the Th1/Th2 and Tc1/Tc2 ratios toward a type 1 response and an increased Th17/Treg ratio, may also be involved in the pathogenesis of PGF. In addition, the presence of DSA may contribute to primary PGF through antibody-dependent cellmediated cytotoxicity, resulting in impairment or apoptosis of $\mathrm{CD}^{+}{ }^{+}$cells in patients with PGF (92).

According to previous studies (4, 26, 27, 81-83). Shi et al. (26) and Wang et al. (27) found that atorvastatin, a regulator of p38 MAPK, may offer a novel therapeutic strategy to promote hematopoietic recovery through repair of the $\mathrm{BM}$ microenvironment in PGF patients. More recently, our group performed two prospective clinical trials. In the first one $(n=$ 68 ), Kong et al. (4) found that EC $<0.1 \%$ in the BM before transplantation identified high-risk patients with PGF and PT. In the second one $(n=35)$, cases with $\mathrm{EC}<0.1 \%$ were treated with oral $\mathrm{N}$-acetyl-L-cysteine (NAC; $400 \mathrm{mg}$, three times per day) from -14 days to +60 days continuously (experiment group); the remaining cases with $\mathrm{EC} \geq 0.1 \%(n=39)$ underwent alloHSCT only (control group). The authors observed a similar survival rate at 10 months after transplantation between the experiment and control groups (4). This study suggests that improvement of the BM microenvironment through EC-directed NAC intervention could be a promising approach to enhance hematopoietic recovery in allo-HSCT settings. Therefore, a randomized, controlled, multicenter study is warranted.

\section{Prophylaxis and Treatment of Virus Infections}

In haplo-SCT with G-CSF modality, the cumulative incidence of cytomegalovirus (CMV) DNAemia varies from 63.7 to $66.1 \%$, which remains one of the main causes of morbidity and mortality. The risk factors for CMV DNAemia include HBsAg seropositivity, acute GVHD before CMV DNAemia, and poor CMV-specific CD8 ${ }^{+} \mathrm{T}$ central memory subset recovery (93). In contrast, transplantation from HLA-mismatched family donors $(P<0.001)$, acute GVHD $(P<0.001)$, and donor-recipient KIR ligand mismatched $(P=0.012)$ were associated with an increased risk of refractory CMV infection $(31,32)$. In addition, refractory CMV infection within 60-100 days after allo-HSCT was an independent risk factor for NRM $(P=0.015)$. Compared to placebo, letermovir prophylaxis can significantly reduce the incidence of CMV disease. For cases with refractory CMV infection/reactivation or who failed ganciclovir, foscarnet, and cidofovir, these adoptive T-cell therapies, for example, CMVspecific T-cell (CMV CTL), represent a promising approach.

In a recent study, 32 patients with refractory CMV infection following haplo-SCT were treated with adoptive transfer of CMV CTL. Pei et al. (33) showed that 27 of the 32 cases exhibited CMV clearance within 4 weeks after treatment without recurrence. Compared with those of the non-refractory CMVinfected patients, the authors observed significantly fewer CMVspecific $\mathrm{CD}^{+} \mathrm{IFN}^{-} \gamma^{+}$and $\mathrm{CD} 4^{+} \mathrm{IFN}-\gamma^{+} \mathrm{T}$ cells. In addition, the CMV clearance is closely correlated with rapid and massive expansion of $\mathrm{CD}^{+}$and $\mathrm{CD} 4^{+} \mathrm{CMV}$ CTL in vivo. Using a humanized HCMV-infected mouse model, the same group further elucidated that systemic HCMV infection could be combated after first-line therapy with CTL through in vivo promotion of the recovery of graft-derived endogenous HCMVspecific CTL (84). These studies provide substantial evidence suggesting that CMV infection could be successfully addressed with prophylaxis, treatment, and adoptive transfer of CMV CTL (84). In summary, future studies should focus on the risk factordirected intervention or development of new drugs for CMV infections in haplo-SCT settings.

\section{Minimal Residual Disease (MRD)-Based Transplant Indication to Decrease Relapse}

MRD determined by multiparameter flow cytometry (MFC) and/or real-time polymerase chain reaction (RT-PCR) at preand post-transplantation could be used for predicting outcomes (Table 2) (5, 94-105) Our group showed that, after two course consolidation therapies, patients with $t_{(8 ; 21)}$ AML could be classified as the low-risk group or high-risk group (106). 
The low-risk group was defined as cases who achieved major molecular remission (MMR)/MRD negativity [>3-log reduction in RUNX1/RUNX1T1 transcripts $(<0.4 \%)$ compared with the pre-treatment baseline of $388 \%$ in our center] after the second consolidation therapy and maintained MMR for 6 months thereafter. The high-risk group was defined as cases not achieving MMR/MRD positivity after the second consolidation therapy or those exhibiting the loss of MMR (defined as RUNX1/RUNX1T1 transcript levels $>0.4 \%$ in MMR patients) within 6 months of achieving MMR. In the high-risk subgroup, compared with cases receiving chemotherapy alone, cases who underwent allo-HSCT experienced a significantly lower cumulative incidence of relapse (CIR, 22.1 vs. 78.9\%, $P<0.0001$ ) and superior DFS (61.7 vs. $19.6 \%, P=0.001)$. However, allo-HSCT was not superior to chemotherapy alone in the low-risk group. Multivariate analysis demonstrated that MRD status and treatment strategy were independent risk factors for CIR and DFS (106). Our results suggest that MRD-directed risk stratification treatment may improve the outcome not only of patients with AML with $t_{(8 ; 21)}$ in CR1 but also of $t_{(8 ; 21)}$ AML cases after two courses of consolidation therapy; thus, allo-HSCT should be performed for those with positive MRD.

More recently, another multicenter study enrolled 229 AML patients with NPM1-mutated (NPM1m). Balsat et al. (107) reported that a $>4-\log$ reduction in $\mathrm{PB}-\mathrm{MRD}$ was significantly associated with a higher relapse incidence and shorter OS. The DFS and OS were significantly improved by allo-HSCT in those with a $>4$-log reduction in PB-MRD. These data suggest that NPM1m PB-MRD may be used as a predictive factor for allo-HSCT indication. Considering the comparable outcomes between haplo-SCT and MSDT, the data reported by Balsat et al. (107) and us (106) suggest that for the abovementioned MRDpositive AML patients who lack MSD, haplo-SCT might be an alternative choice to improve clinical outcomes if there are no MSDs available.

\section{MRD-Based Donor Selection to Decrease Relapse}

In the era of haplo-SCT, MSDT remains the first choice for transplant candidates according to recent literatures $(23,108)$. Recently, Chang et al. (109) showed that, for AML patients with positive pre-transplantation (pre-MRD), haplo-SCT could achieve lower CIR (19 vs. 57\%, $P<0.001$ ) and superior LFS (73 vs. $29 \%, P<0.001$ ) compared with those after MSDT in the retrospective group and prospective group (CIR, 13 vs. $36 \%, P=$ 0.017 and LFS, 80 vs. $48 \%, P=0.007$, respectively). These results were further confirmed in pediatric patients (110) and a subset of AML cases with FLT3-ITD (111), indicating superior graftvs.-leukemia (GVL) effects of haploidentical donors to HLAmatched sibling donors. In another study, 64 Hodgkin lymphoma (HL) patients who relapsed following autologous SCT were treated with haplo-SCT with PT-Cy $(n=30)$ and MSDT $(n=$ 34). After a median follow-up of 47 months, Mariotti et al. (112) found that patients receiving haplo-SCT experienced lower 3year CIR (13 vs. $62 \%, P=0.0001$ ) and better PFS (60 vs. $29 \%$, $P=0.04)$. The authors also indicated that haplo-SCT (HR, 0.17 ,
$P=0.02$ ) was independently associated with a reduced risk of relapse. In a more recent study, 151 consecutive cases with HL who were treated with haplo-SCT $(n=61)$ or MSDT $(n=90)$ were retrospectively enrolled. Gauthier et al. (113) reported a significantly lower GVHD-free/relapse-free survival (GRFS) in the MRDT group compared with those of haplo-SCT based on the PT/CY group $(\mathrm{HR}=0.339, P<0.001)$.

In contrast to the studies reported by other researchers and us, Ringden et al. (114) observed similar risk of relapse between acute leukemia patients who received haploidentical donor grafts $(n=864)$ and those given MSD transplants $(n=9,815)$, suggesting a similar GVL effect. The different results reported by Ringdén et al. and us may be related to the differences in patient population, conditioning regimen, allografts infused, and GVHD prophylaxis.

In summary, studies by others $(36,112,113,115)$ and us $(109,111)$ have suggested the inferiority of MSDT to haplo-SCT, indicating that, for AML patients with positive pre-MRD and HL, haploidentical donors might be selected first in experienced centers, although controversy remains. Therefore, a prospective, randomized study is needed to elucidate which one has better anti-leukemia activity, MSDT or haplo-SCT?

\section{MRD-Directed DLI to Decrease Relapse}

The transplant outcomes are worse for patients who had a hematological relapse after allo-HSCT, including haplo-SCT (116-119). In the past 10 years, a modified DLI (mDLI) protocol was used to treat patients with G-CSF-mobilized peripheral blood harvests, followed by short-term immune suppression, including cyclosporine (CSA) or methotrexate (MTX) $(34,35)$. Compared with traditional DLI, mDLI alleviated the pancytopenia and reduced acute GVHD without influencing the GVL effects. The safety and efficacy of mDLI for prophylaxis and treatment of relapse after haplo-SCT have been well-established. In a prospective study, 814 patients with standard-risk acute leukemia were enrolled. Yan et al. (34) reported that the MRD-positive patients who had mDLI had comparable 3-year CIR (27.8 vs. $18.1 \%$ ) and DFS (55.6 vs. $61.6 \%$ ) compared with those MRDnegative patients. The authors found that factors associated with lower CIR included MRD negative after transplantation (OR = $0.255, P<0.001)$ and receiving DLI $(\mathrm{OR}=0.269, P<0.001)$. Factors correlated with superior DFS included receiving DLI (OR $=0.436, P=0.006)$ and MRD negative after transplantation (OR $=0.511, P=0.001$ ). In a recent study, Yan et al. (35) further showed that, for subjects with refractory/relapsed acute leukemia, MRD- and GVHD-guided multiple DLIs could reduce CIR and improve LFS and OS.

Presently, a number of strategies, including DLI, cellular approaches (NK cells and CAR-T) (117), targeted drugs, hypomethylating agents, IFN- $\gamma$, and blinatumomab (120-122), are currently applied for relapse prevention or treatment in the clinic (116-119). Blinatumomab, a CD3 $\times$ CD19 bispecific antibody, has been approved previously for the treatment of relapsed or refractory $\mathrm{B}$-cell precursor ALL (BCP-ALL). In a recent study $(n=116)$, adults with BCP-ALL in hematologic CR with $\operatorname{MRD}\left(\geq 10^{-3}\right)$ received blinatumomab $15 \mu \mathrm{g} / \mathrm{m}^{2} /$ day by continuous IV infusion for up to four cycles. Patients could 
TABLE 2 | Correlation of MRD with clinical outcomes in patients who underwent Haplo-SCT.

\begin{tabular}{|c|c|c|c|c|c|}
\hline References & Diagnosis (Pt. No.) & Transplant modalities & Methods for MRD & Transplant outcomes & $\begin{array}{l}\text { Multivariate } \\
\text { analysis }\end{array}$ \\
\hline $\begin{array}{l}\text { Zhao et al. } \\
\text { (94) }\end{array}$ & ALL (543) & Haplo-SCT based on G-CSF & MFC & $\begin{array}{l}\text { Positive pre-MRD, except for low level } \\
\text { one (MRD }<0.01 \%) \text {, is correlated with } \\
\text { higher CIR, and inferior LFS. }\end{array}$ & Yes \\
\hline Lv et al. (5) & Intermediate risk AML (78) & Haplo-SCT based on G-CSF & MFC & $\begin{array}{l}\text { Positive MRD (detectable) after } \\
\text { two-cycle consolidation is associated } \\
\text { with higher CIR and inferior survival. }\end{array}$ & Yes \\
\hline Liu et al. (96) & AML (145) & Haplo-SCT based on G-CSF & MFC & $\begin{array}{l}\text { Persistent positive MRD (detectable) } \\
\text { pre-transplantation predicts poor clinical } \\
\text { outcome. }\end{array}$ & Yes \\
\hline $\begin{array}{l}\text { Canaani } \\
\text { et al. (97) }\end{array}$ & AML (393) & $\begin{array}{l}\text { Haplo-SCT based on G-CSF } \\
(27.2 \%) \\
\text { Haplo-SCT with PTCy (66\%) } \\
\text { Haplo-SCT with } \\
\text { G-CSF+PTCy }(6.8 \%)\end{array}$ & MFC & $\begin{array}{l}\text { Positive pre-transplant MRD status } \\
\text { (detectable) is a predictor of poor } \\
\text { prognosis. }\end{array}$ & Yes \\
\hline $\begin{array}{l}\text { Qin et al. } \\
(100)\end{array}$ & AML (14) & $\begin{array}{l}\text { Haplo-SCT based on G-CSF } \\
\text { (79\%) } \\
\text { MSDT (21\%) }\end{array}$ & RT-PCR & $\begin{array}{l}\text { TLS-ERG transcript levels (>1.0\%) } \\
\text { predict high-risk of relapse and inferior } \\
\text { survival. }\end{array}$ & No \\
\hline $\begin{array}{l}\text { Hong et al. } \\
(104)\end{array}$ & B-ALL (28) & $\begin{array}{l}\text { Haplo-SCT based on G-CSF } \\
(90 \%) \\
\text { MSDT (10\%) }\end{array}$ & TR-PCR & $\begin{array}{l}\text { The E2A-PBX1 positive (detectable) after } \\
\text { transplantation is correlated with poor } \\
\text { prognosis. }\end{array}$ & No \\
\hline $\begin{array}{l}\text { Tang et al. } \\
\text { (103) }\end{array}$ & AML (53) & $\begin{array}{l}\text { Haplo-SCT based on G-CSF } \\
(75.5 \%) \\
\text { MSDT }(24.5 \%)\end{array}$ & RT-PCR & $\begin{array}{l}\text { Post-transplant CBFB-MYH11 positive } \\
\text { (defined as } \leq 3-\text { log reduction in } \\
\text { CBFB-MYH11 transcripts compared } \\
\text { with the pre-treatment baseline level) } \\
\text { could predict poor outcomes. }\end{array}$ & No \\
\hline $\begin{array}{l}\text { Zhao et al. } \\
\text { (101) }\end{array}$ & T-ALL (29) & $\begin{array}{l}\text { Haplo-SCT based on G-CSF } \\
(90 \%) \\
\text { MSDT (10\%) }\end{array}$ & RT-PCR & $\begin{array}{l}\text { Pre- or post-transplantation SIL-TAL1 } \\
\text { positive (detectable) is associated with } \\
\text { higher CIR and inferior DFS and OS. }\end{array}$ & No \\
\hline $\begin{array}{l}\text { Zhou et al. } \\
\text { (99) }\end{array}$ & ALL (139) & $\begin{array}{l}\text { Haplo-SCT based on } \\
\text { G-CSF }(76 \%) \\
\text { MSDT }(24 \%)\end{array}$ & MFC & $\begin{array}{l}\text { Positive MRD post-transplantation } \\
\text { (detectable) is associated with high risk } \\
\text { of relapse and inferior survival. }\end{array}$ & Yes \\
\hline $\begin{array}{l}\text { Zhou et al. } \\
\text { (98) }\end{array}$ & $\mathrm{AL}(138)$ & $\begin{array}{l}\text { Haplo-SCT based on G-CSF } \\
(58 \%) \\
\text { MSDT (29\%) } \\
\text { Other alternative } \\
\text { modalities (13\%) }\end{array}$ & RT-PCR & $\begin{array}{l}\text { The WT1 expression level }(\geq 0.60 \%) \text { after } \\
\text { transplantation is associated with higher } \\
\mathrm{CIR} \text { and inferior survival. }\end{array}$ & Yes \\
\hline
\end{tabular}

MRD, minimal residual disease; Haplo-SCT, haploidentical stem cell transplantation; Ref., reference; Pt., patients; No., number; G-CSF, granulocyte colony-stimulating factor; MFC, multiparameter flow cytometry; CIR, cumulative incidence of relapse; LFS, leukemia-free survival; AML, acute myeloid leukemia; PTCy, post-cyclophosphamide; RT-PCR, real-time quantitative polymerase chain reaction; MDST, human leukocyte antigen-matched sibling donor transplantation; AL, acute leukemia.

undergo allo-HSCT at any time after cycle 1. Gökbuget et al. (122) found that $88(78 \%)$ of 113 evaluable patients achieved a complete MRD response. The RFS at 18 months was $54 \%$. Grade 3 or 4 neurologic events occurred in 10 and 3\% of cases, respectively. Four patients (3\%) had cytokine release during cycle
1. These data suggest that blinatumomab could be used not only in treating relapse but only in intervention cases with positive MRD because those responders had significantly longer RFS and OS compared to non-responders. Overall, the available data $(34,35,123)$ suggest that MRD-directed relapse intervention 
could be a simple method in haplo-SCT settings, leading to improved outcomes.

\section{APPLICATION OF G-CSF-PRIMED ALLOGRAFTS IN HAPLO-SCT WITH PTCy}

For the unmanipulated haplo-SCT protocol with PTCy using steady-state bone marrow (SS-BM) as allografts (124), 68 patients with hematological malignancies were enrolled. The authors reported that the CIR at 1 and 2 years following transplantation was 51 and $58 \%$, respectively. Therefore, a number of studies use G-CSF-mobilized peripheral blood harvests (G-PB) as allografts (Table 3) $(7-17,125)$. In a recent multicenter retrospective study from the United States, Bashey et al. (16) compared the outcomes of patients with hematological malignancies who underwent haplo-SCT based on PTCy receiving G-PB $(n=$ $190)$ and SS-BM $(n=481)$. The authors found that there were no significant differences in NRM (G-PB $16 \%$ vs. SS-BM $17 \%$, $P=0.78)$ and $\mathrm{OS}(\mathrm{G}-\mathrm{PB} 57 \%$ vs. SS-BM $54 \%, P=0.52$ ); however, compared to those with SS-BM, cases receiving G-PB experienced a significantly higher incidence of grades II-IV acute GVHD (G-PB $42 \%$ vs. SS-BM 25\%, $P<0.001$ ) and 2 -year chronic GVHD (G-PB $41 \%$ vs. SS-BM $20 \%, P=0.001$ ). The authors demonstrated that patients receiving G-PB had a lower CIR (GPB $28 \%$ vs. SS-BM $45 \%, P<0.001$ ) and superior progression-free survival (G-PB $54 \%$ vs. SS-BM $41 \%, P=0.002$ ).

More recently, a meta-analysis of four comparative retrospective reports and 10 single-arm reports, with a total of 1,759 patients (462 patients received PBSCT, and 1,297 patients received BMT) who received haplo-SCT with PTCy, was performed by Yu et al. (126) They reported that compared with those of the BM group, patients in the PB group experienced a significantly higher incidence of grade II-IV $(\mathrm{OR}=1.778)$ and grade III-IV acute GVHD $(\mathrm{OR}=1.741)$, as well as rapid hematopoietic recovery $(\mathrm{OR}=1.843)$. No significant differences in 2-year CIR, OS, DFS, and chronic GVHD between the two groups were observed. Considering comfort, safety, and speed, G-PB is suitable for haplo-SCT and is currently widely used in the settings of haploidentical allograft with PTCy (126). Thus, multicenter, prospective, randomized studies are warranted to evaluate whether G-PB or BM is the best allograft in the setting of haplo-SCT with PTCy.

\section{FUTURE DIRECTION}

There are several questions that remain to be answered in the field of G-CSF-primed unmanipulated haploidentical blood and marrow transplantation. First, the mechanisms underlying $\mathrm{T}$ cell immune tolerance induced by G-CSF remain to be further investigated. Second, G-CSF-primed bone marrow harvests and/or peripheral blood stem cell harvests have been widely used in unmanipulated haploidentical allografts based on GCSF or haplo-SCT with PTCy. However, we do not know which is the best stem cell source: G-CSF-primed bone marrow harvests, G-CSF-mobilized peripheral stem cell harvests, or a mixture of allografts of both of these harvests? Third, the

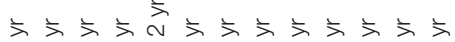
F F F F

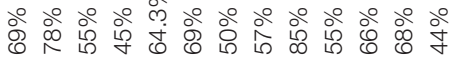

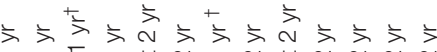

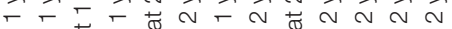

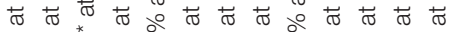

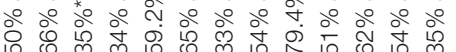

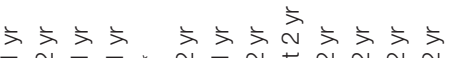

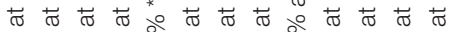

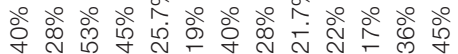

えうううううううううううう

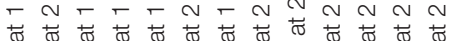

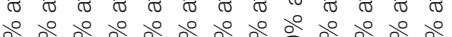

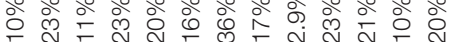

\section{๖}

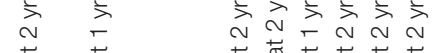
每

$m m m m m m m m m m m$

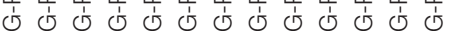


contributions of DSA, that is, impairment of the cell immune and bone marrow niche, to PGF have been identified. More efforts are needed to investigate which methods, available drugs or novel ones, could prevent or treat PGF based on known immune mechanisms underlying this complication. Fourth, more clinical data, especially multicenter, prospective, randomized trials, are needed to confirm the results that haploSCT has a stronger GVL effect compared with MSDT. In addition, the immunological mechanism underlying relapse after transplantation and the stronger GVL effects of haplo-SCT remain to be elucidated. Finally, regarding the MRD-directed intervention, the perfection of MRD detection methods and establishment of novel intervention strategies, such as new generation CAR-T, will further improve transplant outcomes.

In summary, several haplo-SCT protocols have been established worldwide (Tables 1, 3), but each one has both disadvantages and advantages. No haplo-SCT modality could be widely accepted by each transplantation center as a standard approach for the treatment of hematological malignancies, IMD, and genetic diseases. More recently, our group demonstrated that the addition of low-dose PTCy to the Beijing Protocol can further enhance the G-CSF/ATG-induced GVHD protective activity, leading to a superior survival. A similar attempt has also been made by other researchers. In addition, with the deep understanding of the underlying mechanisms behind transplant

\section{REFERENCES}

1. Appelbaum FR. Hematopoietic-cell transplantation at 50. $N$ Engl J Med. (2007) 357:1472-5. doi: 10.1056/NEJMp078166

2. Pei $X$, Huang $X$. New approaches in allogenic transplantation in AML. Semin Hematol. (2019) 56:147-54. doi: 10.1053/j.seminhematol.2018.08.007

3. Luznik L, O’Donnell PV, Symons HJ, Chen AR, Leffell MS, Zahurak M, et al. HLA-haploidentical bone marrow transplantation for hematologic malignancies using nonmyeloablative conditioning and high-dose, posttransplantation cyclophosphamide. Biol Blood Marrow Transplant. (2008) 14:641-50. doi: 10.1016/j.bbmt.2008.03.005

4. Kong Y, Wang Y, Zhang YY, Shi MM, Mo XD, Sun YQ, et al. Prophylactic oral NAC reduced poor hematopoietic reconstitution by improving endothelial cells after haploidentical transplantation. Blood Adv. (2019) 3:1303-17. doi: 10.1182/bloodadvances.2018029454

5. Lv M, Wang Y, Chang YJ, Zhang XH, Xu LP, Jiang Q, et al. Myeloablative haploidentical transplantation is superior to chemotherapy for patients with intermediate-risk acute myelogenous leukemia in first complete remission. Clin Cancer Res. (2019) 25:1737-48. doi: 10.1158/1078-0432.CCR-18-1637

6. McCurdy SR, Kanakry JA, Showel MM, Tsai HL, Bolaños-Meade J, Rosner GL, et al. Risk-stratified outcomes of nonmyeloablative HLA-haploidentical BMT with high-dose posttransplantation cyclophosphamide. Blood. (2015) 125:3024-31. doi: 10.1182/blood-2015-01-623991

7. Wang Y, Wu DP, Liu QF, Xu LP, Liu KY, Zhang XH, et al. Donor and recipient age, gender and $\mathrm{ABO}$ incompatibility regardless of donor source: validated criteria for donor selection for haematopoietic transplants. Leukemia. (2018) 32:492-8. doi: 10.1038/leu.2017.199

8. Nakamae H, Koh H, Katayama T, Nishimoto M, Hayashi Y, Nakashima Y, et al. HLA haploidentical peripheral blood stem cell transplantation using reduced dose of posttransplantation cyclophosphamide for poor-prognosis or refractory leukemia and myelodysplastic syndrome. Exp Hematol. (2015) 43:921-9.e921. doi: 10.1016/j.exphem.2015.07.006

9. Raj K, Pagliuca A, Bradstock K, Noriega V, Potter V, Streetly M, et al. Peripheral blood hematopoietic stem cells for transplantation of complications, such as PGF, virus infection, and relapse, novel methods for the prevention and treatment of these complications will be established. All of these will further improve the outcomes of haplo-SCT. In this regard, well-designed prospective clinical trials are needed to compare the outcomes of the currently available haplo-SCT protocols and complication prevention and treatment methods, as well as to establish better treatments and prophylaxis for patients who had PGF, virus infection, and relapse after haploidentical allografts.

\section{AUTHOR CONTRIBUTIONS}

$\mathrm{X}-\mathrm{JH}$ designed the study. X-YZ and Y-JC collected data, analyzed the data, and drafted the manuscript. All authors contributed to data interpretation, manuscript preparation, and approval of the final version.

\section{FUNDING}

This work was supported by Beijing Municipal Science and Technology Commission (Z18111000960000), the Foundation for Innovative Research Groups of the National Natural Science Foundation of China (81621001), and the National Key Research and Development Program of China (2017YFA0104500). hematological diseases from related, haploidentical donors after reducedintensity conditioning. Biol Blood Marrow Transplant. (2014) 20:890-5. doi: 10.1016/j.bbmt.2014.03.003

10. Sugita J, Kawashima N, Fujisaki T, Kakihana K, Ota S, Matsuo K, et al. HLA-haploidentical peripheral blood stem cell transplantation with post-transplant cyclophosphamide after busulfan-containing reducedintensity conditioning. Biol Blood Marrow Transplant. (2015) 21:1646-52. doi: 10.1016/j.bbmt.2015.06.008

11. Jaiswal SR, Chakrabarti A, Chatterjee S, Bhargava S, Ray K, O’Donnell P, et al. Haploidentical peripheral blood stem cell transplantation with posttransplantation cyclophosphamide in children with advanced acute leukemia with fludarabine-, busulfan-, and melphalan-based conditioning. Biol Blood Marrow Transplant. (2016) 22:499-504. doi: 10.1016/j.bbmt.2015.11.010

12. Moiseev IS, Pirogova OV, Alyanski AL, Babenko EV, Gindina TL, Darskaya EI, et al. Graft-versus-host disease prophylaxis in unrelated peripheral blood stem cell transplantation with post-transplantation cyclophosphamide, tacrolimus, and mycophenolate mofetil. Biol Blood Marrow Transplant. (2016) 22:1037-42. doi: 10.1016/j.bbmt.2016.03.004

13. Gonzalez-Llano O, Gonzalez-Lopez EE, Ramirez-Cazares AC, Marcos-Ramirez ER, Ruiz-Arguelles GJ, Gomez-Almaguer D. Haploidentical peripheral blood stem cell transplantation with posttransplant cyclophosphamide in children and adolescents with hematological malignancies. Pediatr Blood Cancer. (2016) 63:2033-7. doi: $10.1002 / \mathrm{pbc} .26131$

14. Hong KT, Kang HJ, Choi JY, Hong CR, Cheon JE, Park JD, et al. Favorable outcome of post-transplantation cyclophosphamide haploidentical peripheral blood stem cell transplantation with targeted busulfan-based myeloablative conditioning using intensive pharmacokinetic monitoring in pediatric patients. Biol Blood Marrow Transplant. (2018) 24:2239-44. doi: 10.1016/j.bbmt.2018.06.034

15. Ruggeri A, Labopin M, Bacigalupo A, Gülbas Z, Koc Y, Blaise D, et al. Bone marrow versus mobilized peripheral blood stem cells in haploidentical transplants using posttransplantation cyclophosphamide. Cancer. (2018) 124:1428-37. doi: $10.1002 / \mathrm{cncr} .31228$ 
16. Bashey A, Zhang MJ, McCurdy SR, St Martin A, Argall T, Anasetti C, et al. Mobilized peripheral blood stem cells versus unstimulated bone marrow as a graft source for T-cell-replete haploidentical donor transplantation using post-transplant cyclophosphamide. J Clin Oncol. (2017) 35:3002-9. doi: 10.1200/JCO.2017.72.8428

17. Granata A, Fürst S, Bramanti S, Legrand F, Sarina B, Harbi S, et al. Peripheral blood stem cell for haploidentical transplantation with post-transplant high dose cyclophosphamide: detailed analysis of 181 consecutive patients. Bone Marrow Transplant. (2019). doi: 10.1038/s41409-019-0500-x. [Epub ahead of print].

18. Sugita J, Kagaya Y, Miyamoto T, Shibasaki Y, Nagafuji K, Ota S, et al. Myeloablative and reduced-intensity conditioning in HLA-haploidentical peripheral blood stem cell transplantation using post-transplant cyclophosphamide. Bone Marrow Transplant. (2019) 54:432-41. doi: 10.1038/s41409-018-0279-1

19. Chang YJ, Xu LP, Wang Y, Zhang XH, Chen H, Chen YH, et al. Controlled, randomized, open-label trial of risk-stratified corticosteroid prevention of acute graft-versus-host disease after haploidentical transplantation. J Clin Oncol. (2016) 34:1855-63. doi: 10.1200/JCO.2015.63.8817

20. Lv M, Chang Y, Huang X. Everyone has a donor: contribution of the Chinese experience to global practice of haploidentical hematopoietic stem cell transplantation. Front Med. (2019) 13:45-56. doi: 10.1007/s11684-017-0595-7

21. Chang YJ, Huang XJ. Haploidentical SCT: the mechanisms underlying the crossing of HLA barriers. Bone Marrow Transplant. (2014) 49:873-9. doi: $10.1038 / \mathrm{bmt} .2014 .19$

22. Chang YJ, Huang XJ. Improving the clinical outcome of unmanipulated haploidentical blood and marrow transplantation. Bone Marrow Transplant. (2015) 50(Suppl 2):S21-3. doi: 10.1038/bmt.2015.90

23. Chang YJ, Luznik L, Fuchs EJ, Huang XJ. How do we choose the best donor for T-cell-replete, HLA-haploidentical transplantation? J Hematol Oncol. (2016) 9:35. doi: 10.1186/s13045-016-0265-2

24. Chang YJ, Huang XJ. Haploidentical hematopoietic stem cell transplantation with unmanipulated granulocyte colony stimulating factor mobilized marrow and blood grafts. Curr Opin Hematol. (2012) 19:454-61. doi: 10.1097/MOH.0b013e3283582322

25. Chang YJ, Huang XJ. Haploidentical stem cell transplantation: antithymocyte globulin-based experience. Semin Hematol. (2016) 53:82-9. doi: 10.1053/j.seminhematol.2016.01.004

26. Shi MM, Kong Y, Song Y, Sun YQ, Wang Y, Zhang XH, et al. Atorvastatin enhances endothelial cell function in posttransplant poor graft function. Blood. (2016) 128:2988-99. doi: 10.1182/blood-2016-03702803

27. Wang YT, Kong Y, Song Y, Han W, Zhang YY, Zhang XH, et al. Increased type 1 immune response in the bone marrow immune microenvironment of patients with poor graft function after allogeneic hematopoietic stem cell transplantation. Biol Blood Marrow Transplant. (2016) 22:1376-82. doi: 10.1016/j.bbmt.2016.04.016

28. Kong Y, Cao XN, Zhang XH, Shi MM, Lai YY, Wang Y, et al. Atorvastatin enhances bone marrow endothelial cell function in corticosteroidresistant immune thrombocytopenia patients. Blood. (2018) 131:1219-33. doi: 10.1182/blood-2017-09-807248

29. Mainardi C, Ebinger M, Enkel S, Feuchtinger T, Teltschik HM, Eyrich M, et al. CD34(+) selected stem cell boosts can improve poor graft function after paediatric allogeneic stem cell transplantation. Br J Haematol. (2018) 180:90-9. doi: 10.1111/bjh.15012

30. Ghobadi A, Fiala MA, Ramsingh G, Gao F, Abboud CN, StockerlGoldstein K, et al. Fresh or cryopreserved CD34(+)-selected mobilized peripheral blood stem and progenitor cells for the treatment of poor graft function after allogeneic hematopoietic cell transplantation. Biol Blood Marrow Transplant. (2017) 23:1072-7. doi: 10.1016/j.bbmt.2017. 03.019

31. Liu J, Kong J, Chang YJ, Chen H, Chen YH, Han W, et al. Patients with refractory cytomegalovirus (CMV) infection following allogeneic haematopoietic stem cell transplantation are at high risk for CMV disease and non-relapse mortality. Clin Microbiol Infect. (2015) 21:1121.e9-15. doi: 10.1016/j.cmi.2015.06.009
32. Zhao XY, Luo XY, Yu XX, Zhao XS, Han TT, Chang YJ, et al. Recipient-donor KIR ligand matching prevents CMV reactivation posthaploidentical T cell-replete transplantation. Br J Haematol. (2017) 177:76681. doi: 10.1111/bjh.14622

33. Pei XY, Zhao XY, Chang YJ, Liu J, Xu LP, Wang Y, et al. Cytomegalovirusspecific $\mathrm{T}$-cell transfer for refractory cytomegalovirus infection after haploidentical stem cell transplantation: the quantitative and qualitative immune recovery for cytomegalovirus. J Infect Dis. (2017) 216:945-56. doi: 10.1093/infdis/jix357

34. Yan $\mathrm{CH}$, Liu DH, Liu KY, Xu LP, Liu YR, Chen $\mathrm{H}$, et al. Risk stratification-directed donor lymphocyte infusion could reduce relapse of standard-risk acute leukemia patients after allogeneic hematopoietic stem cell transplantation. Blood. (2012) 119:3256-62. doi: 10.1182/blood-2011-09-380386

35. Yan CH, Liu QF, Wu DP, Zhang X, Xu LP, Zhang XH, et al. Prophylactic donor lymphocyte infusion (DLI) followed by minimal residual disease and graft-versus-host disease-guided multiple DLIs could improve outcomes after allogeneic hematopoietic stem cell transplantation in patients with refractory/relapsed acute leukemia. Biol Blood Marrow Transplant. (2017) 23:1311-9. doi: 10.1016/j.bbmt.2017.04.028

36. Chen D, Zhou D, Guo D, Xu P, Chen B. Comparison of outcomes in hematological malignancies treated with haploidentical or HLAidentical sibling hematopoietic stem cell transplantation following myeloablative conditioning: a meta-analysis. PLoS ONE. (2018) 13:e0191955. doi: 10.1371/journal.pone.0191955

37. Wang K, Lv M, Chang YJ, Zhao XY, Zhao XS, Zhang YY, et al. Early myeloidderived suppressor cells (HLA-DR(-)/(low)CD33(+)CD16(-)) expanded by granulocyte colony-stimulating factor prevent acute graft-versus-host disease (GVHD) in humanized mouse and might contribute to lower GVHD in patients post allo-HSCT. J Hematol Oncol. (2019) 12:31. doi: 10.1186/s13045-019-0710-0

38. Yu XX, Han TT, Xu LL, Chang YJ, Huang XJ, Zhao XY. Effect of the in vivo application of granulocyte colony-stimulating factor on NK cells in bone marrow and peripheral blood. J Cell Mol Med. (2018) 22:3025-34. doi: $10.1111 /$ jcmm.13539

39. Perobelli SM, Mercadante AC, Galvani RG, Gonçalves-Silva T, Alves AP, Pereira-Neves A, et al. G-CSF-induced suppressor IL-10+ neutrophils promote regulatory $\mathrm{T}$ cells that inhibit graft-versus-host disease in a long-lasting and specific way. J Immunol. (2016) 197:3725-34. doi: 10.4049/jimmunol.1502023

40. D'Aveni M, Rossignol J, Coman T, Sivakumaran S, Henderson S, Manzo T, et al. G-CSF mobilizes CD34+ regulatory monocytes that inhibit graft-versus-host disease. Sci Transl Med. (2015) 7:281 ra242. doi: 10.1126/scitranslmed.3010435

41. Morris ES, MacDonald KP, Rowe V, Johnson DH, Banovic T, Clouston AD, et al. Donor treatment with pegylated G-CSF augments the generation of IL-10-producing regulatory $\mathrm{T}$ cells and promotes transplantation tolerance. Blood. (2004) 103:3573-81. doi: 10.1182/blood-2003-08-2864

42. Melve GK, Ersvaer E, Eide GE, Kristoffersen EK, Bruserud Ø. Peripheral blood stem cell mobilization in healthy donors by granulocyte colonystimulating factor causes preferential mobilization of lymphocyte subsets. Front Immunol. (2018) 9:845. doi: 10.3389/fimmu.2018.00845

43. MacDonald KP, Le Texier L, Zhang P, Morris H, Kuns RD, Lineburg KE, et al. Modification of $\mathrm{T}$ cell responses by stem cell mobilization requires direct signaling of the T cell by G-CSF and IL-10. J Immunol. (2014) 192:3180-9. doi: 10.4049/jimmunol.1302315

44. Rossetti M, Gregori S, Roncarolo MG. Granulocyte-colony stimulating factor drives the in vitro differentiation of human dendritic cells that induce anergy in naive T cells. Eur J Immunol. (2010) 40:3097-106. doi: 10.1002/eji.201040659

45. Franzke A, Piao W, Lauber J, Gatzlaff P, Könecke C, Hansen W, et al. G-CSF as immune regulator in $\mathrm{T}$ cells expressing the G-CSF receptor: implications for transplantation and autoimmune diseases. Blood. (2003) 102:734-9. doi: 10.1182/blood-2002-04-1200

46. Rutella S, Zavala F, Danese S, Kared H, Leone G. Granulocyte colonystimulating factor: a novel mediator of T cell tolerance. J Immunol. (2005) 175:7085-91. doi: 10.4049/jimmunol.175.11.7085 
47. Hu Y, He GL, Zhao XY, Zhao XS, Wang Y, Xu LP, et al. Regulatory $B$ cells promote graft-versus-host disease prevention and maintain graftversus-leukemia activity following allogeneic bone marrow transplantation. Oncoimmunology. (2017) 6:e1284721. doi: 10.1080/2162402X.2017.1284721

48. Xuan L, Wu X, Qiu D, Gao L, Liu H, Fan Z, et al. Regulatory gammadelta $\mathrm{T}$ cells induced by G-CSF participate in acute graftversus-host disease regulation in G-CSF-mobilized allogeneic peripheral blood stem cell transplantation. J Transl Med. (2018) 16:144. doi: 10.1186/s12967-018-1519-2

49. Marini O, Costa S, Bevilacqua D, Calzetti F, Tamassia N, Spina C, et al. Mature $\mathrm{CD} 10(+)$ and immature CD10(-) neutrophils present in G-CSFtreated donors display opposite effects on T cells. Blood. (2017) 129:1343-56. doi: 10.1182/blood-2016-04-713206

50. Ringdén O, Labopin M, Gorin NC, Le Blanc K, Rocha V, Gluckman E, et al. Treatment with granulocyte colony-stimulating factor after allogeneic bone marrow transplantation for acute leukemia increases the risk of graft-versushost disease and death: a study from the Acute Leukemia Working Party of the European Group for Blood and Marrow Transplantation. J Clin Oncol. (2004) 22:416-23. doi: 10.1200/JCO.2004.06.102

51. Kobayashi S, Imamura M, Hashino S, Noto S, Mori A, Tanaka J, et al. Possible role of granulocyte colony-stimulating factor in increased serum soluble interleukin-2 receptor-alpha levels after allogeneic bone marrow transplantation. Leuk Lymphoma. (1999) 33:559-66. doi: 10.3109/10428199909058460

52. Xu LP, Wu DP, Han MZ, Huang H, Liu QF, Liu DH, et al. A review of hematopoietic cell transplantation in China: data and trends during 20082016. Bone Marrow Transplant. (2017) 52:1512-8. doi: 10.1038/bmt.2017.59

53. Di Bartolomeo P, Santarone S, De Angelis G, Picardi A, Cudillo L, Cerretti $\mathrm{R}$, et al. Haploidentical, unmanipulated, G-CSF-primed bone marrow transplantation for patients with high-risk hematologic malignancies. Blood. (2013) 121:849-57. doi: 10.1182/blood-2012-08-453399

54. Wang Y, Liu QF, Xu LP, Liu KY, Zhang XH, Ma X, et al. Haploidentical vs. identical-sibling transplant for AML in remission: a multicenter, prospective study. Blood. (2015) 125:3956-62. doi: 10.1182/blood-2015-02-627786

55. Wang Y, Liu QF, Xu LP, Liu KY, Zhang XH, Ma X, et al. Haploidentical versus matched-sibling transplant in adults with philadelphia-negative highrisk acute lymphoblastic leukemia: a biologically phase III randomized study. Clin Cancer Res. (2016) 22:3467-76. doi: 10.1158/1078-0432.CCR-15-2335

56. Han LJ, Wang Y, Fan ZP, Huang F, Zhou J, Fu YW, et al. Haploidentical transplantation compared with matched sibling and unrelated donor transplantation for adults with standard-risk acute lymphoblastic leukaemia in first complete remission. Br J Haematol. (2017) 179:120-30. doi: 10.1111/bjh.14854

57. Wang Y, Wang HX, Lai YR, Sun ZM, Wu DP, Jiang M, et al. Haploidentical transplant for myelodysplastic syndrome: registry-based comparison with identical sibling transplant. Leukemia. (2016) 30:2055-63. doi: 10.1038/leu.2016.110

58. Yang B, Yu R, Cai L, Bin Guo, Chen H, Zhang H, et al. Haploidentical versus matched donor stem cell transplantation for patients with hematological malignancies: a systemic review and meta-analysis. Bone Marrow Transplant. (2019) 54:99-122. doi: 10.1038/s41409-018-0239-9

59. Martínez C, Gayoso J, Canals C, Finel H, Peggs K, Dominietto A, et al. Posttransplantation cyclophosphamide-based haploidentical transplantation as alternative to matched sibling or unrelated donor transplantation for hodgkin lymphoma: a registry study of the lymphoma working party of the European Society for Blood and Marrow Transplantation. J Clin Oncol. (2017) 35:3425-32. doi: 10.1200/JCO.2017.72.6869

60. How J, Slade M, Vu K, DiPersio JF, Westervelt P, Uy GL, et al. T cellreplete peripheral blood haploidentical hematopoietic cell transplantation with post-transplantation cyclophosphamide results in outcomes similar to transplantation from traditionally matched donors in active disease acute myeloid leukemia. Biol Blood Marrow Transplant. (2017) 23:648-53. doi: 10.1016/j.bbmt.2017.01.068

61. McCurdy SR, Kasamon YL, Kanakry CG, Bolaños-Meade J, Tsai HL, Showel MM, et al. Comparable composite endpoints after HLA-matched and HLAhaploidentical transplantation with post-transplantation cyclophosphamide. Haematologica. (2017) 102:391-400. doi: 10.3324/haematol.2016.144139
62. Ghosh N, Karmali R, Rocha V, Ahn KW, DiGilio A, Hari PN, et al. Reducedintensity transplantation for lymphomas using haploidentical related donors versus HLA-matched sibling donors: a center for international blood and marrow transplant research analysis. J Clin Oncol. (2016) 34:3141-9. doi: 10.1200/JCO.2015.66.3476

63. Bashey ZA, Zhang X, Brown S, Jackson K, Morris LE, Holland HK, et al. Comparison of outcomes following transplantation with T-replete HLA-haploidentical donors using post-transplant cyclophosphamide to matched related and unrelated donors for patients with AML and MDS aged 60 years or older. Bone Marrow Transplant. (2018) 53:756-63. doi: 10.1038/s41409-018-0126-4

64. Brissot E, Labopin M, Ehninger G, Stelljes M, Brecht A, Ganser A, et al. Haploidentical versus unrelated allogeneic stem cell transplantation for relapsed/refractory acute myeloid leukemia: a report on 1578 patients from the Acute Leukemia Working Party of the EBMT. Haematologica. (2019) 104:524-32. doi: 10.3324/haematol.2017.187450

65. Li S, Wang B, Fu L, Pang Y, Zhu G, Zhou X, et al. Hematopoietic stem cell transplantation without in vivo T-cell depletion for pediatric aplastic anemia: a single-center experience. Pediatr Transplant. (2018) 22:e13204. doi: $10.1111 /$ petr.13204

66. Liu Z, Zhang Y, Xiao H, Yao Z, Zhang H, Liu Q, et al. Cotransplantation of bone marrow-derived mesenchymal stem cells in haploidentical hematopoietic stem cell transplantation in patients with severe aplastic anemia: an interim summary for a multicenter phase II trial results. Bone Marrow Transplant. (2017) 52:704-10. doi: 10.1038/bmt.2016.347

67. Xu LP, Jin S, Wang SQ, Xia LH, Bai H, Gao SJ, et al. Upfront haploidentical transplant for acquired severe aplastic anemia: registry-based comparison with matched related transplant. J Hematol Oncol. (2017) 10:25. doi: 10.1186/s13045-017-0398-y

68. Xu LP, Zhang XH, Wang FR, Mo XD, Han TT, Han W, et al. Haploidentical transplantation for pediatric patients with acquired severe aplastic anemia. Bone Marrow Transplant. (2017) 52:381-7. doi: 10.1038/bmt.2016.281

69. Li Y, Duan F, Xiao H, Wu X, Wang S, Xu D, et al. Therapeutic outcomes of haploidentical allogeneic hematopoietic stem cell transplantation in patients with severe aplastic anemia: a multicenter study. Transplantation. (2018) 102:1724-31. doi: 10.1097/TP.0000000000002200

70. Lu Y, Sun RJ, Zhao YL, Xiong M, Cao XY, Zhang JP, et al. Unmanipulated haploidentical hematopoietic stem cell transplantation achieved outcomes comparable with matched unrelated donor transplantation in young acquired severe aplastic anemia. Biol Blood Marrow Transplant. (2018) 24:1881-7. doi: 10.1016/j.bbmt.2018.05.015

71. Yue C, Ding Y, Gao Y, Li L, Pang Y, Liu Z, et al. Cotransplantation of haploidentical hematopoietic stem cells and allogeneic bone marrow-derived mesenchymal stromal cells as a first-line treatment in very severe aplastic anemia patients with refractory infections. Eur J Haematol. (2018) 100:624-9. doi: 10.1111/ejh.13060

72. Wang Z, Yu H, Cao F, Liu Z, Liu Z, Feng W, et al. Donor-derived marrow mesenchymal stromal cell co-transplantation following a haploidentical hematopoietic stem cell transplantation trail to treat severe aplastic anemia in children. Ann Hematol. (2019) 98:473-9. doi: 10.1007/s00277-018-3523-2

73. Xu ZL, Zhou M, Jia JS, Mo WJ, Zhang XH, Zhang YP, et al. Immunosuppressive therapy versus haploidentical transplantation in adults with acquired severe aplastic anemia. Bone Marrow Transplant. (2019) 54:1319-26. doi: 10.1038/s41409-018-0410-3

74. Yang S, Yuan X, Ma R, Jiang L, Guo J, Zang Y, et al. Comparison of outcomes of frontline immunosuppressive therapy and frontline haploidentical hematopoietic stem cell transplantation for children with severe aplastic anemia who lack an HLA-matched sibling donor. Biol Blood Marrow Transplant. (2019) 25:975-80. doi: 10.1016/j.bbmt.2019.01.017

75. Zeng Y, Wang S, Wang J, Liu L, Su Y, Lu Z, et al. Optimal donor for severe aplastic anemia patient requiring allogeneic hematopoietic stem cell transplantation: a large-sample study from China. Sci Rep. (2018) 8:2479. doi: 10.1038/s41598-018-20853-9

76. Xu LP, Wang SQ, Wu DP, Wang JM, Gao SJ, Jiang M, et al. Haplo-identical transplantation for acquired severe aplastic anaemia in a multicentre prospective study. Br J Haematol. (2016) 175:265-74. doi: 10.1111/bjh.1 4225 
77. Young NS. Aplastic anemia. N Engl J Med. (2018) 379:1643-56. doi: 10.1056/NEJMra1413485

78. Sun Q, Wu B, Lan H, Meng F, Ma X, Chen X, et al. Haploidentical haematopoietic stem cell transplantation for thalassaemia major based on an FBCA conditioning regimen. Br J Haematol. (2018) 182:554-8. doi: $10.1111 /$ bjh. 15438

79. Chen Y, Xu LP, Zhang XH, Chen H, Wang FR, Liu KY, et al. Busulfan, fludarabine, and cyclophosphamide (BFC) conditioning allowed stable engraftment after haplo-identical allogeneic stem cell transplantation in children with adrenoleukodystrophy and mucopolysaccharidosis. Bone Marrow Transplant. (2018) 53:770-3. doi: 10.1038/s41409-018-0175-8

80. Liu X, Wu M, Peng Y, Chen X, Sun J, Huang F, et al. Improvement in poor graft function after allogeneic hematopoietic stem cell transplantation upon administration of mesenchymal stem cells from third-party donors: a pilot prospective study. Cell Transplant. (2014) 23:1087-98. doi: 10.3727/096368912X661319

81. Kong Y, Chang YJ, Wang YZ, Chen YH, Han W, Wang Y, et al. Association of an impaired bone marrow microenvironment with secondary poor graft function after allogeneic hematopoietic stem cell transplantation. Biol Blood Marrow Transplant. (2013) 19:1465-73. doi: 10.1016/j.bbmt.2013.07.014

82. Kong Y, Wang YT, Cao XN, Song Y, Chen YH, Sun YQ, et al. Aberrant T cell responses in the bone marrow microenvironment of patients with poor graft function after allogeneic hematopoietic stem cell transplantation. J Transl Med. (2017) 15:57. doi: 10.1186/s12967-017-1159-y

83. Kong Y, Wang YT, Hu Y, Han W, Chang YJ, Zhang XH, et al. The bone marrow microenvironment is similarly impaired in allogeneic hematopoietic stem cell transplantation patients with early and late poor graft function. Bone Marrow Transplant. (2016) 51:249-55. doi: 10.1038/bmt.2015.229

84. Zhao XY, Pei XY, Chang YJ, Yu XX, Xu LP, Wang Y, et al. Firstline therapy with donor-derived HCMV-specific T cells reduces persistent HCMV infection by promoting antiviral immunity after allogenic stem cell transplantation. Clin Infect Dis. (2019) 2019:ciz368. doi: 10.1093/cid/ciz368

85. Ciurea SO, Thall PF, Milton DR, Barnes TH, Kongtim P, Carmazzi Y, et al. Complement-binding donor-specific anti-HLA antibodies and risk of primary graft failure in hematopoietic stem cell transplantation. Biol Blood Marrow Transplant. (2015) 21:1392-8. doi: 10.1016/j.bbmt.2015.05.001

86. Chang YJ, Zhao XY, Xu LP, Zhang XH, Wang Y, Han W, et al. Donorspecific anti-human leukocyte antigen antibodies were associated with primary graft failure after unmanipulated haploidentical blood and marrow transplantation: a prospective study with randomly assigned training and validation sets. J Hematol Oncol. (2015) 8:84. doi: 10.1186/s13045-015-0182-9

87. Sun YQ, Wang Y, Zhang XH, Xu LP, Liu KY, Yan CH, et al. Virus reactivation and low dose of CD34+ cell, rather than haploidentical transplantation, were associated with secondary poor graft function within the first 100 days after allogeneic stem cell transplantation. Ann Hematol. (2019) 98:1877-83. doi: 10.1007/s00277-019-03715-w

88. Ciurea SO, Cao K, Fernandez-Vina M, Kongtim P, Malki MA, Fuchs E, et al. The European Society for Blood and Marrow Transplantation (EBMT) consensus guidelines for the detection and treatment of donor-specific antihla antibodies (DSA) in haploidentical hematopoietic cell transplantation. Bone Marrow Transplant. (2018) 53:521-34. doi: 10.1038/s41409-017-0062-8

89. Tang C, Chen F, Kong D, Ma Q, Dai H, Yin J, et al. Successful treatment of secondary poor graft function post allogeneic hematopoietic stem cell transplantation with eltrombopag. J Hematol Oncol. (2018) 11:103. doi: 10.1186/s13045-018-0649-6

90. Fu H, Zhang X, Han T, Mo X, Wang Y, Chen H, et al. Eltrombopag is an effective and safe therapy for refractory thrombocytopenia after haploidentical hematopoietic stem cell transplantation. Bone Marrow Transplant. (2019) 54:1310-8. doi: 10.1038/s41409-019-0435-2

91. Marotta S, Marano L, Ricci P, Cacace F, Frieri C, Simeone L, et al. Eltrombopag for post-transplant cytopenias due to poor graft function. Bone Marrow Transplant. (2019) 54:1346-53. doi: 10.1038/s41409-019-0442-3

92. Bramanti S, Calafiore V, Longhi E, Mariotti J, Crespiatico L, Sarina B, et al. Donor-specific anti-HLA antibodies in haploidentical stem cell transplantation with post-transplantation cyclophosphamide: risk of graft failure, poor graft function, and impact on outcomes. Biol Blood Marrow Transplant. (2019) 25:1395-1406. doi: 10.1016/j.bbmt.2019.02.020
93. Chen Y, Xu LP, Liu KY, Chen H, Chen YH, Zhang XH, et al. Risk factors for cytomegalovirus DNAemia following haploidentical stem cell transplantation and its association with host hepatitis B virus serostatus. $J$ Clin Virol. (2016) 75:10-5. doi: 10.1016/j.jcv.2015.12.003

94. Zhao XS, Liu YR, Xu LP, Wang Y, Zhang XH, Chen H, et al. Minimal residual disease status determined by multiparametric flow cytometry pretransplantation predicts the outcome of patients with ALL receiving unmanipulated haploidentical allografts. Am J Hematol. (2019) 94:512-21. doi: 10.1002/ajh.25417

95. Liu J, Ma R, Liu YR, Xu LP, Zhang XH, Chen $H$, et al. The significance of peri-transplantation minimal residual disease assessed by multiparameter flow cytometry on outcomes for adult AML patients receiving haploidentical allografts. Bone Marrow Transplant. (2019) 54:56777. doi: 10.1038/s41409-018-0300-8

96. Liu J, Zhao XS, Liu YR, Xu LP, Zhang XH, Chen $\mathrm{H}$, et al. Association of persistent minimal residual disease with poor outcomes of patients with acute myeloid leukemia undergoing allogeneic hematopoietic stem cell transplantation. Chin Med J. (2018) 131:2808-16. doi: 10.4103/0366-6999.246072

97. Canaani J, Labopin M, Huang XJ, Ciceri F, Van Lint MT, Bruno B, et al. Minimal residual disease status predicts outcome of acute myeloid leukaemia patients undergoing T-cell replete haploidentical transplantation. An analysis from the Acute Leukaemia Working Party (ALWP) of the European Society for Blood and Marrow Transplantation (EBMT). $\mathrm{Br} J$ Haematol. (2018) 183:411-20. doi: 10.1111/bjh.15540

98. Zhao XS, Jin S, Zhu HH, Xu LP, Liu DH, Chen H, et al. Wilms' tumor gene 1 expression: an independent acute leukemia prognostic indicator following allogeneic hematopoietic SCT. Bone Marrow Transplant. (2012) 47:499-507. doi: 10.1038/bmt.2011.121

99. Zhao XS, Liu YR, Zhu HH, Xu LP, Liu DH, Liu KY, et al. Monitoring MRD with flow cytometry: an effective method to predict relapse for ALL patients after allogeneic hematopoietic stem cell transplantation. Ann Hematol. (2012) 91:183-92. doi: 10.1007/s00277-011-1285-1

100. Qin YZ, Chen Y, Xu LP, Wang Y, Zhang XH, Chen H, et al. Outcome and minimal residual disease monitoring in patients with $t(16 ; 21)$ acute myelogenous leukemia undergoing allogeneic hematopoietic stem cell transplantation. Biol Blood Marrow Transplant. (2018) 24:163-8. doi: 10.1016/j.bbmt.2017.09.002

101. Zhao X, Hong Y, Qin Y, Xu Y, Chang Y, Wang Y, et al. The clinical significance of monitoring the expression of the SIL-TAL1 fusion gene in T-cell acute lymphoblastic leukemia after allogeneic hematopoietic stem cell transplantation. Int J Lab Hematol. (2017) 39:613-9. doi: 10.1111/ijlh.12711

102. Wang Y, Wu DP, Liu QF, Qin YZ, Wang JB, Xu LP, et al. In adults with $\mathrm{t}(8 ; 21) \mathrm{AML}$, posttransplant RUNX1/RUNX1T1-based MRD monitoring, rather than c-KIT mutations, allows further risk stratification. Blood. (2014) 124:1880-6. doi: 10.1182/blood-2014-03-563403

103. Tang FF, Xu LP, Zhang XH, Chen H, Chen YH, Han W, et al. Monitoring of post-transplant CBFB-MYH11 as minimal residual disease, rather than KIT mutations, can predict relapse after allogeneic haematopoietic cell transplantation in adults with inv(16) acute myeloid leukaemia. $\mathrm{Br} \mathrm{J}$ Haematol. (2018) 180:448-51. doi: 10.1111/bjh.14340

104. Hong Y, Zhao X, Qin Y, Zhou S, Chang Y, Wang Y, et al. The prognostic role of E2A-PBX1 expression detected by real-time quantitative reverse transcriptase polymerase chain reaction (RQPCR) in B cell acute lymphoblastic leukemia after allogeneic hematopoietic stem cell transplantation. Ann Hematol. (2018) 97:1547-54. doi: 10.1007/s00277-018-3338-1

105. Liu J, Wang Y, Xu LP, Liu DH, Qin YZ, Chang YJ, et al. Monitoring mixed lineage leukemia expression may help identify patients with mixed lineage leukemia-rearranged acute leukemia who are at high risk of relapse after allogeneic hematopoietic stem cell transplantation. Biol Blood Marrow Transplant. (2014) 20:929-36. doi: 10.1016/j.bbmt.2014.03.008

106. Zhu HH, Zhang XH, Qin YZ, Liu DH, Jiang H, Chen H, et al. MRD-directed risk stratification treatment may improve outcomes of $t(8 ; 21)$ AML in the first complete remission: results from the AML05 multicenter trial. Blood. (2013) 121:4056-62. doi: 10.1182/blood-2012-11-468348

107. Balsat M, Renneville A, Thomas X, de Botton S, Caillot D, Marceau $\mathrm{A}$, et al. Postinduction minimal residual disease predicts outcome and 
benefit from allogeneic stem cell transplantation in acute myeloid leukemia with NPM1 mutation: a study by the acute leukemia french association group. J Clin Oncol. (2017) 35:185-93. doi: 10.1200/JCO.2016.6 7.1875

108. Ciurea SO, Al Malki MM, Kongtim P, Fuchs EJ, Luznik L, Huang XJ, et al. The European Society for Blood and Marrow Transplantation (EBMT) consensus recommendations for donor selection in haploidentical hematopoietic cell transplantation. Bone Marrow Transplant. (2019). doi: 10.1038/s41409-019-0499-z. [Epub ahead of print].

109. Chang YJ, Wang Y, Liu YR, Xu LP, Zhang XH, Chen H, et al. Haploidentical allograft is superior to matched sibling donor allograft in eradicating pretransplantation minimal residual disease of AML patients as determined by multiparameter flow cytometry: a retrospective and prospective analysis. $J$ Hematol Oncol. (2017) 10:134. doi: 10.1186/s13045-017-0502-3

110. Chang YJ, Zhao XS, Wang Y, Liu YR, Xu LP, Zhang XH, et al. Effects of preand post-transplantation minimal residual disease on outcomes in pediatric patients with acute myeloid leukemia receiving human leukocyte antigenmatched or mismatched related donor allografts. Am J Hematol. (2017) 92:E659-61. doi: 10.1002/ajh.24910

111. Zhao X, Wang Z, Ruan G, Liu Y, Wang Y, Zhang X, et al. Impact of pre-transplantation minimal residual disease determined by multiparameter flow cytometry on the outcome of AML patients with FLT3-ITD after allogeneic stem cell transplantation. Ann Hematol. (2018) 97:967-75. doi: 10.1007/s00277-018-3265-1

112. Mariotti J, Devillier R, Bramanti S, Sarina B, Furst S, Granata A, et al. T cell-replete haploidentical transplantation with post-transplantation cyclophosphamide for hodgkin lymphoma relapsed after autologous transplantation: reduced incidence of relapse and of chronic graft-versushost disease compared with HLA-identical related donors. Biol Blood Marrow Transplant. (2018) 24:627-32. doi: 10.1016/j.bbmt.2017.11.030

113. Gauthier J, Poiré X, Gac AC, Leclerc M, Guillaume T, Chalandon Y, et al. Better outcome with haploidentical over HLA-matched related donors in patients with Hodgkin's lymphoma undergoing allogeneic haematopoietic cell transplantation-a study by the Francophone Society of Bone Marrow Transplantation and Cellular Therapy. Bone Marrow Transplant. (2018) 53:400-9. doi: 10.1038/s41409-017-0018-z

114. Ringdén O, Labopin M, Ciceri F, Velardi A, Bacigalupo A, Arcese W, et al. Is there a stronger graft-versus-leukemia effect using HLA-haploidentical donors compared with HLA-identical siblings? Leukemia. (2016) 30:447-55. doi: 10.1038/leu.2015.232

115. Luo Y, Xiao H, Lai X, Shi J, Tan Y, He J, et al. T-cell-replete haploidentical HSCT with low-dose anti-T-lymphocyte globulin compared with matched sibling HSCT and unrelated HSCT. Blood. (2014) 124:273543. doi: 10.1182/blood-2014-04-571570

116. Fleischhauer K, Hsu KC, Shaw BE. Prevention of relapse after allogeneic hematopoietic cell transplantation by donor and cell source selection. Bone Marrow Transplant. (2018) 53:1498-507. doi: 10.1038/s41409-018-0218-1

117. Cooley S, Parham P, Miller JS. Strategies to activate NK cells to prevent relapse and induce remission following hematopoietic stem cell transplantation. Blood. (2018) 131:1053-62. doi: 10.1182/blood-2017-08-752170

118. Mo XD, Tang BL, Zhang XH, Zheng CC, Xu LP, Zhu XY, et al. Comparison of outcomes after umbilical cord blood and unmanipulated haploidentical hematopoietic stem cell transplantation in children with high-risk acute lymphoblastic leukemia. Int J Cancer. (2016) 139:2106-15. doi: 10.1002/ijc.30249

119. Wang $\mathrm{Y}$, Chen $\mathrm{H}$, Chen J, Han $\mathrm{M}$, Hu J, Jiong $\mathrm{Hu}$, et al. The consensus on the monitoring, treatment, and prevention of leukemia relapse after allogeneic hematopoietic stem cell transplantation in China. Cancer Lett. (2018) 438:63-75. doi: 10.1016/j.canlet.2018. 08.030

120. Stein AS, Kantarjian H, Gökbuget N, Bargou R, Litzow MR, Rambaldi A, et al. Blinatumomab for acute lymphoblastic leukemia relapse after allogeneic hematopoietic stem cell transplantation. Biol Blood Marrow Transplant. (2019) 25:1498-504. doi: 10.1016/j.bbmt.2019. 04.010

121. Jen EY, Xu Q, Schetter A, Przepiorka D, Shen YL, Roscoe D, et al. FDA approval: blinatumomab for patients with B-cell precursor acute lymphoblastic leukemia in morphologic remission with minimal residual disease. Clin Cancer Res. (2019) 25:473-7. doi: 10.1158/1078-0432.CCR-18-2337

122. Gökbuget N, Dombret H, Bonifacio M, Reichle A, Graux C, Faul C, et al. Blinatumomab for minimal residual disease in adults with Bcell precursor acute lymphoblastic leukemia. Blood. (2018) 131:1522-31. doi: 10.1182/blood-2017-08-798322

123. Tan Y, Du K, Luo Y, Shi J, Cao L, Zheng Y, et al. Superiority of preemptive donor lymphocyte infusion based on minimal residual disease in acute leukemia patients after allogeneic hematopoietic stem cell transplantation. Transfusion. (2014) 54:1493-500. doi: 10.1111/trf.12524

124. Brodsky RA, Luznik L, Bolaños-Meade J, Leffell MS, Jones RJ, Fuchs EJ. Reduced intensity HLA-haploidentical BMT with post transplantation cyclophosphamide in nonmalignant hematologic diseases. Bone Marrow Transplant. (2008) 42:523-7. doi: 10.1038/bmt.2 008.203

125. Solomon SR, Sizemore CA, Sanacore M, Zhang X, Brown S, Holland $\mathrm{HK}$, et al. Haploidentical transplantation using $\mathrm{T}$ cell replete peripheral blood stem cells and myeloablative conditioning in patients with highrisk hematologic malignancies who lack conventional donors is well tolerated and produces excellent relapse-free survival: results of a prospective phase II trial. Biol Blood Marrow Transplant. (2012) 18:1859-66. doi: 10.1016/j.bbmt.2012.06.019

126. Yu X, Liu L, Xie Z, Dong C, Zhao L, Zhang J, et al. Bone marrow versus peripheral blood as a graft source for haploidentical donor transplantation in adults using post-transplant cyclophosphamide-A systematic review and meta-analysis. Crit Rev Oncol Hematol. (2019) 133:120-8. doi: 10.1016/j.critrevonc.2018. 05.017

Conflict of Interest: The authors declare that the research was conducted in the absence of any commercial or financial relationships that could be construed as a potential conflict of interest.

Copyright (C) 2019 Chang, Zhao and Huang. This is an open-access article distributed under the terms of the Creative Commons Attribution License (CC BY). The use, distribution or reproduction in other forums is permitted, provided the original author(s) and the copyright owner(s) are credited and that the original publication in this journal is cited, in accordance with accepted academic practice. No use, distribution or reproduction is permitted which does not comply with these terms. 